\title{
CCAR Breira Statement
}

\author{
1977
}

The two documents below, which are discussed in Professor Michael Meyer's commentary, relate to Breira, an organization with which Leonard Beerman was closely associated. It arose in 1973 as an "alternative" (the English word for breira) to the existing policies of Jewish organizations toward the Israeli-Palestinian conflict. Founded by the Chicago-based Reform rabbi Arnold J. Wolf, the organization was devoted to a two-state solution well before that idea, as Professor Meyer notes, became a mainstream principle in the American Jewish community. As a result, it was cast as a radical deviation from Jewish communal norms and was widely criticized in the community.

Accustomed to and undaunted by the adoption of controversial positions, Beerman worked with his friend and colleague Rabbi Richard Levy to establish a presence for Breira in Los Angeles. They worked with Yoav Peled, an Israeli graduate student at UCLA and later political scientist at Tel Aviv University, to bring together progressive Jews, including Rabbis David Berner, Laura Geller, Sandy Ragins, and Chaim Seidler-Feller, to support the cause of Breira, which ceased to exist in 1977.

\section{COMMENTARY BY PROFESSOR MICHAEL A. MEYER}

The failure of the Israeli government to recognize the existence of a Palestinian entity and the expanding settlement in the West Bank led in the mid-197os to the formation of a Jewish organization known as Breira (Alternative). It included a considerable proportion of non-Orthodox rabbis, who were committed to the Jewish state but critical of its current policies. The organization was ahead of its 
The Rabbinate and the Middle Fast:

DISSENT IN THE JENISH COMNUNITY

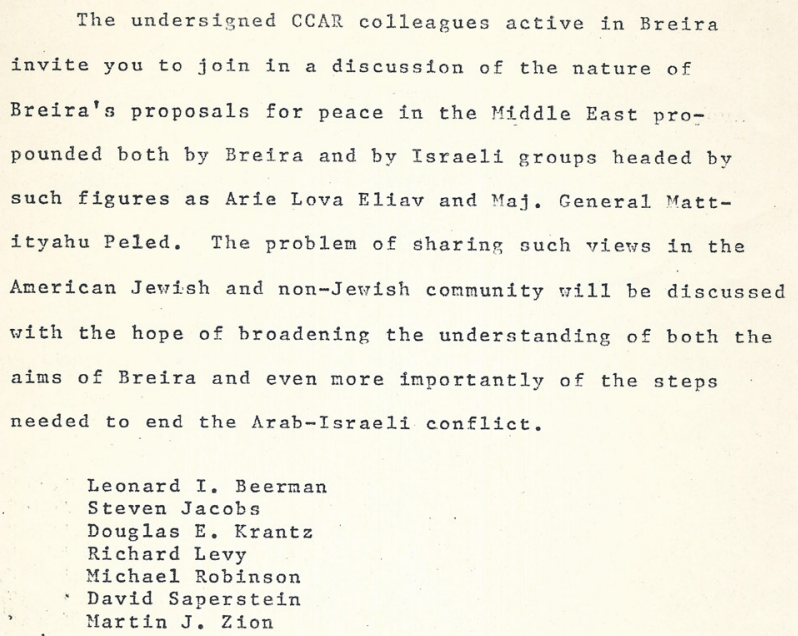

COLONIAL ROOM

FIGURE 19. CCAR letter on Breira (1977).

time in coming out strongly for a two-state solution when that was still strictly a minority view among American Jews.

The Jewish establishment soon took aim at Breira, claiming that its views were damaging to the State of Israel. The organization was demonized, and its members, including myself, for a time suffered ostracism. Nonetheless, during a period of 


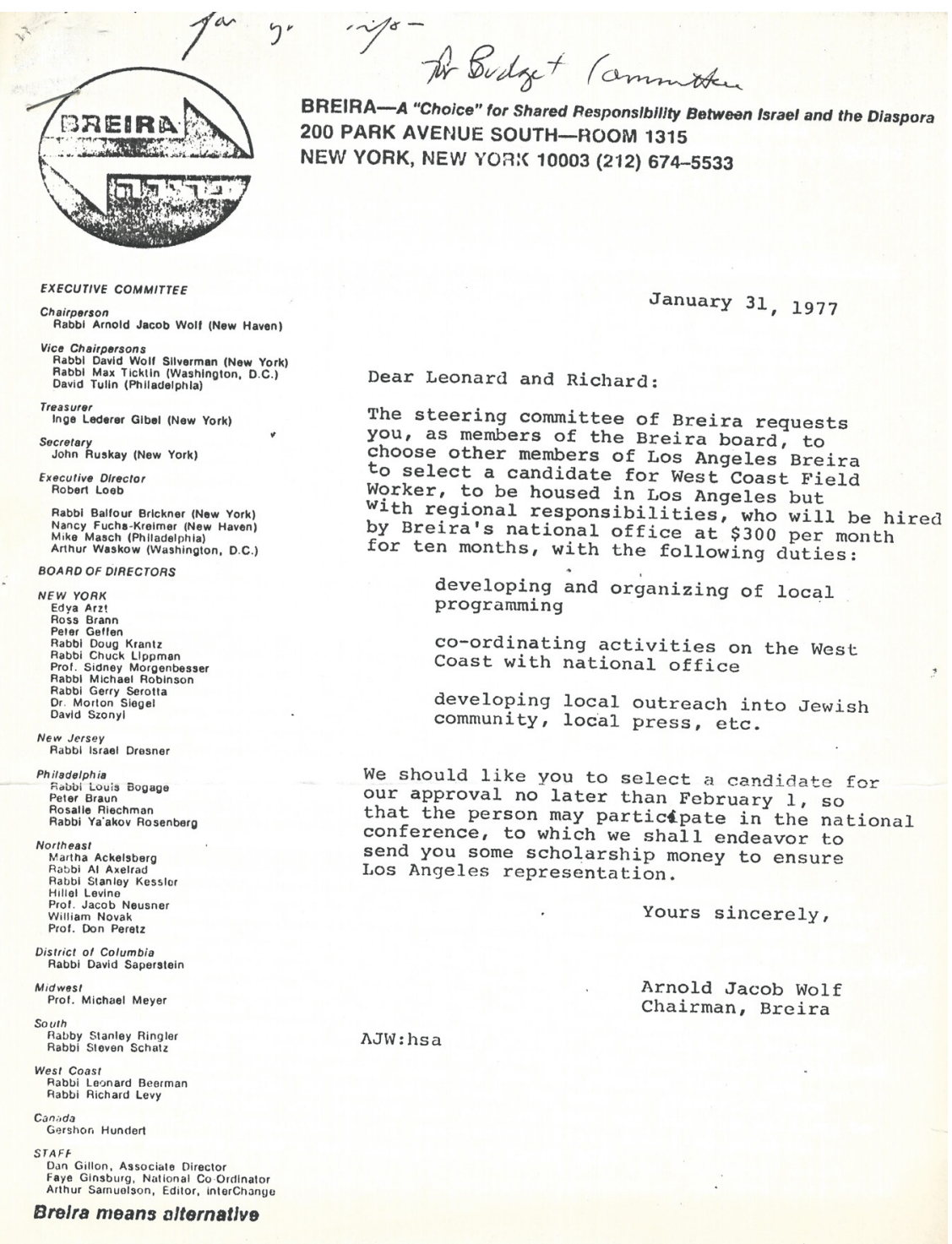

FIGURE 20. Breira letterhead (1977).

about half a decade, Breira was able to publicize its views both within and outside the Jewish community.

It is not surprising that Rabbi Leonard Beerman should have associated himself with Breira. He had shown his commitment to Zionism when, as a rabbinical student, he joined the Haganah, the pre-state Jewish military, in 1947. He continued 
to be a lover of Israel, but a moral critic of its policies, even as, in various areas, he criticized policies of the United States. The brief undated document, which he signed together with other Reform rabbis, indicates that he sought to bring the message of Breira to his rabbinical colleagues in the Central Conference of American Rabbis, most likely at its convention in June 1977. The second document, a letter to Leonard and Richard Levy dated January 31, 1977, shows the Breira letterhead. 